\title{
ANALOGIJA U PRAVU: ZNAČENJE I UPOTREBA
}

Sažetak: Zaključivanje na temelju analogije javlja se u svakodnevnom životu $i$ raznim područjima ljudskog djelovanja, pa tako i u pravu. Zaključivanje na temelju analogije u pravu, na prvi pogled, može se svesti na istu formu kao i zaključivanje na temelju analogije uopće - dvije premise i zaključak. No, ono se ipak razlikuje od općeg analogijskog zaključivanja, jer jedna premisa u pravnom zaključivanju mora biti normativna (a ne samo faktična).

Analogijsko zaključivanje (uopće i u pravu) izučava se od strane velikog broja autora i s raznih pristupa. Suglasnost postoji samo u pogledu elementarnog oblika analogijskog zaključivanja za koji možemo reći da se zasniva na sličnosti dvaju predmeta (dviju pojava) u nekim osobinama, pa se onda na temelju te sličnosti zaključuje da su ti predmeti (pojave), slični i u nekim drugim osobinama.

Što se tiče analogije u pravu, ističemo posebno njezina četiri oblika: zakonska analogija (analogia legis), pravna analogija (analogia iuris), analogia inter legem te analogija koja se koristi u precedentnom pravu. Njima se, osim što se pravne norme tumače, i popunjavaju pravne praznine (s time da popunjavanja pravnih praznina nema u kaznenom pravu). Posebno interesantno i sporno jest kada se to radi na temelju pravnih načela.

Ključne riječi: $\quad$ zaključivanje na temelju analogije, sličnost, precedenti, popunjavanje pravnih praznina, pravna načela

\section{UVOD}

Zaključivanje na temelju analogije javlja se u svim područjima društvenog života, ${ }^{1}$ pa tako i u pravu. Što se tiče prava, ne bi bilo ispravno reći da postoji posebna pravna analogija, jer se mnoga pitanja koja su postavljaju u analogijskom zaključivanju uopće, odnose i na analogiju u pravu. Ali, analogijsko zaključivanje u pravu ima neke osobitosti, na koje ćemo ukazati.

* Dr. sc. Žaklina Harašić, izvanredna profesorica na Katedri za teoriju prava i države Pravnog fakulteta Sveučilišta u Splitu, Domovinskog rata 8, 21000 Split, Republika Hrvatska. Adresa e-pošte: zaklina.harasic@pravst.hr. ORCID: https://orcid. org/0000-0002-4395-3114.

1 Analogijsko zaključivanje temeljno je ljudskom mišljenju, ali moglo bi se argumentirati da je svojstveno i životinjama. Tako: Baltha, P., Analogy and Analogical Reasoning, The Stanford Encyclopedia of Philosophy, (Winter 2016 edition), Edward N. Zalta (ed.). https://plato.stanford.edu/archives/Winter 2016//entries/reasoning-analogy/, pristupljeno 27. prosinca 2017. 
Dakle, zaključivanje s pomoću analogije javlja se, kako u svakodnevnom životu, tako i drugim područjima (izvan prava), npr. filozofiji (analogija je sličnost ili različitost koja se određuje "prema odnosu", ili "u odnosu", tj. vrsta spoznaje bića na temelju njegova odnosa spram nekog drugog bića, s pomoću usporedbe; pretpostavka analogije spoznaje jest analogija bitka, odnosno sličnost i različitost bića u njihovu opstojanju), ${ }^{2}$ fizici (riječ je o podudarnosti različitih sustava fizike /električnih, mehaničkih, akustičkih i dr./ s obzirom na njihovo dinamičko vladanje, što predstavlja tzv. fizičku analogiju), ${ }^{3}$ biologiji (riječ je o strukturnoj analogiji ili analogiji na temelju podudarnosti građe sustava koje su osobito prikladne za proučavanje bioloških sustava), ${ }^{4}$ matematici (analogija predstavlja jednakost odnosa među brojevima), ${ }^{5}$ lingvistici (analogija se shvaća kao težnja za stvaranjem ili preinačavanjem riječi ili oblika riječi prema modelima koji im prvotno ne pripadaju). ${ }^{6}$

Analogija (uopće i u pravu) izučava se od strane velikog broja autora i s raznih pristupa. Suglasnost postoji samo u pogledu elementarnog oblika analogijskog zaključivanja, za kojeg možemo reći da se zasniva na sličnosti dva predmeta (dvije pojave) u nekim osobinama, pa se onda na temelju te sličnosti, zaključuje da su ti predmeti (pojave), slični i u nekim drugim osobinama.

Problem sa suvremenim klasifikacijama zaključivanja na temelju analogije jest u tome što autori upotrebljavaju različite riječi da bi klasificirali ono što je u biti ista vrsta analogijskog argumenta, te općenito upotrebljavaju različite parametre da bi klasificirali ovaj argument. ${ }^{7}$ Tako da bi se označile različite komparacije između sličnih stvari koriste se termini poput "proporcija” ("proportion"), "sličnost” ("similarity”), "isto" ("same”), "figura” ("figure”), "sličan” ("simile"), "metafora" ("metaphor") i "usporedba" ("comparison”). Ovi termini mogu se odnositi na analogiju u bilo kojem smislu. ${ }^{8}$ Autor smatra da treba praviti i distinkciju između različitih primjena istog tipa argumenta i različitih tipova argumenata. ${ }^{9}$ Ili, isto tako, da bi se razlikovali objekti komparacije, koriste se izrazi poput: "source vs. target" (izvor v. cilj), "source-case vs. target-case” (izvorni slučaj v. ciljni slučaj), "primary subject vs. analogue” (osnovni predmet v. analog), "source domain vs. target domain" (izvorna domena v. ciljna domena), "case vs. parallel case” (slučaj v. paralelni slučaj). Osim toga, argumenti u pogledu kojih se pravi potpodjela prema njihovim funkcijama, mogu se dalje potpodijeliti ako razmatramo različite logičke forme. ${ }^{10}$

Prema nekim autorima analogija ima centralnu ulogu u pravnom rasuđivanju. To kažu autori koji se bave analogijskim rasuđivanjem u pravu uopće, kao i oni koji se posebno bave

\footnotetext{
2 Kutleša, S., (ur.) Filozofski leksikon, Leksikografski zavod Miroslav Krleža, Zagreb, 2012., str. 30.

3 "Analogija", Hrvatska enciklopedija. http://www.enciklopedija.hr/natuknica.aspx?id=2471, pristupljeno 19. kolovoza 2017.

4 "Analogija", op. cit. u bilj. 3.

5 "Analogija", op. cit. u bilj. 3.

6 "Analogija", op. cit. u bilj. 3.

7 Juthe, A., A Systematic Review of Classification of Argument by Analogy, u: Ribeiro Jales, H., (ur.) Systematic Approaches to Argument by Analogy, Springer, 2014., str. 109.

8 Juthe, A Systemastic..., op. cit. u bilj. 7, str. 110.

9 Juthe, A Systematic..., op. cit. u bilj. 7, str. 111. 
rasuđivanjem u sistemu civilnog prava, odnosno common law sistemu. ${ }^{11}$ Nerhot čak kaže da je rasuđivanje na temelju analogije potpuno misteriozan tip rasuđivanja. ${ }^{12}$ Štoviše, prema nekima pravni komentatori uzrokuju goleme probleme propuštajući objasniti kako se analogija razlikuje od srodnih procesa zaključivanja - indukcije i metafore. ${ }^{13}$ Općenito, pravne teorije prihvaćaju praktičnu korist rasuđivanja na temelju analogije, ali naglašavaju njegova ograničenja. ${ }^{14}$ Osim toga, problem je i što se sam termin "analogija" upotrebljava u više značenja, ${ }^{15} \mathrm{i}$ pitanje je što to treba biti analogno. Tako Maris kaže da dok prema Perelmanu može biti riječ o usporedbi slučajeva iz dva sistema pozitivnog prava, suprotno usporedbi između slučajeva koji su izvedeni iz sistema prirodnog prava, dotle je analogijsko rasuđivanje prema Marisu specifična primjena principa univerzalnosti, koji zahtijeva da se isti slučajevi tretiraju jednako. ${ }^{16}$

Rasuđivanje na temelju analogije, prema nekim je autorima, i temeljna common law metoda. ${ }^{17}$ Ali se i ističe da je sve donedavno bilo relativno malo analiza, osim kao dio doktrine precedenta. ${ }^{18}$ Ipak, za neke tradicionalno slavljenje analogijskog rezoniranja leži na drhtavim temeljima, često služeći tome da maskira dimenziju donošenja pravnog argumenta i pravnog odlučivanja. ${ }^{19}$

Dakle, u tekstu ćemo obraditi sljedeća pitanja: o zaključivanju na temelju analogije općenito u njegovu osnovnom obliku (t. 2.), o vrstama zaključivanja na temelju analogije općenito (t. 3.), o kvalificiranoj sličnosti (a ne običnoj) kod zaključivanja na temelju analogije - "bitnoj" sličnosti, koja se temelji na ratiu (t. 4.), o faktičnom i normativnom svojstvu premisa u analogijskom zaključivanju (t. 5.), o zaključivanju na temelju raznih vrsta analogija u pravu (t. 6.), o odnosu precedenta i analogije (t.7.), o pojmu i brojnost pravnih praznina, budući da se one popunjavaju s pomoću analogije (t. 8.), o pojmu pravnih načela, s obzirom na to da je i zaključivanjem i preko njih riječ o jednoj vrsti analogijskog zaključivanja (t. 9.), o nekim vrstama pravnih načela (t. 10.) te o popunjavanju pravnih praznina kao tehnike za upotpunjavanje pravnog sistema (t. 11.).

11 Posebno ističemo autore koji daju veliku ulogu analogijskom zaključivanju u pravu i uopće (jer, ne daju svi autori koji se bave analogijom istoj veliku ulogu), npr. Hunter, D.,Teaching and Using Analogy in Law, Journal of the Association of Legal Writting Directors, 2008., str. 151. https://ssrn.com/abstract=1089669, pristupljeno 20. listopada 2017.; Damele, G., Analogia Legis and Analogia Iuris: An Overwiev from a Rhetorical Perspective, u: Ribeiro Jales, H., (ur.) Systematic Approaches to Argument by Analogy, Springer, 2014., str. 243.; Lamond, G., Precedent and Analogy in Legal Reasoning, The Stanford Encyclopedia of Philosophy (spring 2016 Edition), Edward N. Zalta (ed.) https://plato.stanford.edu/archives/Spr 2016/entries/legal-reas-prec/, pristupljeno 27. prosinca 2017.

Nerhot, P., Introduction, u: Nerhot, P., (ur.) Legal Knowledge and Analogy. Fragments of Legal Epistemology, Hermeneutics and Liguistics, Springer Science+Business Media, B. V., 1991., str. 1. Hunter, op. cit. u bilj. 11, str. 152. Farrar, J., Reasoning by Analogy in the Law, Bond Law Review, god. 9, br. 2, 1997., str. 172. Na raznolikost predloženih pristupa ukazuje npr. Nerhot, op. cit. u bilj. 12, str. 2.

Maris Cees, V., Milking the Meter - On Analogy, Universalizability, u: Nerhot, P., (ur.) Legal Knowledge and Analogy. Fragments of Legal Epistemology, Hermeneutics and Liguistics, Springer Science+Business Media, B. V., 1991., str. 73.

17 Autori koji daju veliku ulogu analogijskom zaključivanju u common law sistemu su npr., Farrar, op. cit. u bilj. 14, str. 149.; Damele, op. cit. u bilj.11, str. 243.; Lamond, op. cit. u bilj. 11; Schauer, F., Spellman, B., Analogy, Expertise, and Experience, The University of Chicago Law Review, god. 84, 2017., str. 249. 


\section{ZAKLJUČIVANJE NA TEMELJU ANALOGIJE - ELEMENTARNI OBLIK}

Možemo reći da se analogijski zaključak zasniva na sličnosti dvaju predmeta (dviju pojava) u nekim osobinama, ${ }^{20}$ pa se onda na temelju te sličnosti zaključuje da su ti predmeti (te pojave), slični i u nekim drugim osobinama, za koje prethodno nismo znali da su im slične. ${ }^{21}$

To simbolički možemo prikazati:

A i B su slični.

A ima svojstvo $\mathrm{p}$.

Dakle (vjerojatno) i B ima svojstvo p.

Ili, s većim brojem osobina:

A i B su slični s obzirom na osobine $p, q$ i s.

A ima daljnju osobinu $\mathrm{x}$.

Stoga, i B vjerojatno ima osobinu $\mathrm{x}$.

Međutim, analogijsko zaključivanje ne mora biti pouzdano, tj. ne mora nužno voditi do točnog zaključka.

Primjer:

A. A. i B. B. su stari ljudi. Oboje imaju 80 godina, slabo čuju i slabo vide.

A. A. ima proširene vene.

Stoga i B. B. ima proširene vene.

Koliko će analogijski zaključak biti pouzdan, to ovisi o više faktora, kao što su npr. naše znanje o pojavama o kojima izvodimo analogiju, od što veće sličnosti između njih, odnosno od što manje razlika između njih. ${ }^{22}$

Prikazat ćemo u literaturi vrlo zastupljeno korištenje simbola "S" - source (domain) (izvorna domena), i “T” - target (domain) (ciljna domena), s istim načinom oblikovanja premisa, a onda i zaključka, kao u gornjim primjerima:

$S$ je sličan $T$ u određenim osobinama.

$S$ ima neke dalje osobine $Q$.

20 Jesu li "analogija" $i$ "sličnost" homonimi? Rekli bismo da jesu, i u hrvatskom jeziku se "analogija" prevodi kao "sličnost". Prema nekim stajalištima biti analogan i biti sličan nije isto. Neka svojstva mogu biti objektivno slična, ali ne i analogna. Npr. automobili Porsche i Chervolet stoje oko 40.000 dolara. Porsche je odlične kvalitete. Stoga je vjerojatno i Chervolet također izvrsne kvalitete. Ovaj argument se temelji na sličnosti. Argument na temelju analogije svakako uključuje sličnost i možda može biti promatran kao vrsta generičkog tipa argumenta na temelju sličnosti (Juthe, A., Argument by Analogy, Argumentation, god. 19, br. 1, 2005. str. 7. https://doi.org/10.1007/s10503-005-2314-9/, pristupljeno 20. listopada 2017.

21 Vasić, R.; Jovanović, D.; Dajović, G., Uvod u pravo, Pravni fakultet Univerziteta u Beogradu, Centar za izdavaštvo i informisanje, Dosije Studio, Beograd, 2014., str. 371. 
Stoga, $T$ također ima osobine $Q$, ili neke osobine $Q^{*}$ slične $Q .{ }^{23}$

Ne želimo čitatelja zbunjivati s načinima analogijskog zaključivanja koji se svode na isti elementarni vid, ali s druge strane, želimo prikazati različitu upotrebu simbola, pa navodimo još dvije sheme, koje su prema Waltonu, jednom od vodećih predstavnika u analogijskom zaključivanju, vjerojatno najprihvaćenije, odnosno najdominantnije u udžbenicima logike.

\section{Shema 1:}

Općenito, slučaj C1 je sličan slučaju C2.

A je istinito (pogrešno) u slučaju $C 1$.

Zaključak: A je istinito (pogrešno) u slučaju C2. ${ }^{24}$

Shema 2 izgledala bi ovako:

Entiteti a, b, c, d imaju svojstva P i Q.

A, b, c imaju svojstvo R.

Stoga d vjerojatno ima svojstvo R. ${ }^{25}$

$C=$ "case".

\section{VRSTE ZAKLJUČIVANJA NA TEMELJU ANALOGIJE}

Za Van Emerena i Garsena postoje dvije temeljne varijante argumenta analogije, i to: deskriptivna i normativna. ${ }^{26}$ Tipična karakteristika deskriptivne analogijske argumentacije jest to da su stajalište koje se brani, i razlog koji se daje njemu u potporu, deskriptivni: u obje propozicije određeno stanje stvari je izraženo. ${ }^{27} \mathrm{Npr}$. kamera nadzor u centru Amsterdama je efikasan, zato što se u Londonu kamera nadzor pokazao korisnim. U ovoj argumentaciji dvije stvari su komparirane koje pripadaju istoj vrsti (London i Amsterdam su gradovi), stajalište koje se brani jest da je kamera nadzor u Amsterdamu efikasan, a razlog kojim se to podupire - da se kamera nadzor već pokazao korisnim u Londonu. Odnosno, zahtijeva se da je nešto slučaj u Amsterdamu, zato što je to već slučaj u Londonu. ${ }^{28}$

Shema kod Balta, op. cit. u bilj. 1.

Shema kod Walton, D. N., Argumentation Shemes for Argument from Analogy, u: Ribeiro Jales, H., (ur.) Systematic Approaches to Argument by Analogy, Springer, 2014., str. 24.

Walton, op. cit. u bilj. 24, str. 28.

Van Emeren, F. H., Garsen, B., Argumentation by Analogy in Stereotypical Argumentative Patterns, u: Ribeiro Jales, H., (ur.) Systematic Approaches to Argument by Analogy, Springer, 2014., str. 47.

Loc. cit.

Van Emeren, Garsen, op. cit. u bilj. 26, str. 48. 
U normativnoj analogijskoj argumentaciji središnju ulogu ima načelo konzistencije. Ono zahtijeva da se stvar, situacija, osoba, grupa ili institucija spomenuta u stajalištu pripada istoj kategoriji kao stvar, situacija itd., trebaju tretirati na isti način. ${ }^{29} \mathrm{Npr}$. zaposlenici u administrativnom odjelu trebali bi dobiti povišicu plaće, jer ostale zaposlene osobe u tvrtki također dobivaju povišicu plaće. ${ }^{30}$

Macagno definira analogiju kao rasuđivanje koje se temelji na apstrakciji općeg svojstva koje je izvučeno iz dva komparabilna entiteta ili stanja. Tako analogijsko rasuđivanje uključuje dvije različite procedure: odnos između dva termina komparacije i općeg svojstva, koje im je zajedničko, kao i odnos između ovog zajedničkog općeg svojstva i entiteta koji su sumpsumirani pod to opće svojstvo, u kojem su tvrdnja ili klasifikacija uključeni. ${ }^{31}$

Predložena argumentacijska shema za argument na temelju analogije izgledala bi ovako:

Viša premisa: općenito, slučaj C1 sličan je u slučaju C2

Niža premisa: svojstvo A je istinito (pogrešno) u slučaju $C 1$

Zaključak: svojstvo A je istinito (pogrešno) u slučaju C2. ${ }^{32}$

Možemo primijetiti da je ovaj način zaključivanja isti kao i kod Waltonove prve sheme. ${ }^{33}$

Juthe razlikuje četiri temeljna argumenta, od kojih je jedan argument na temelju analogije. ${ }^{34}$ Ostali su deduktivni argument, induktivni argument i ne-deduktivno zaključivanje. ${ }^{35}$ Kod deduktivnog argumenta zaključak slijedi nužno iz istinitih premisa, zahvaljujući njihovoj semantici ili sintaksi. ${ }^{36}$ Kod induktivnog argumenta (o kojem je mnogo diskutirano u filozofskoj tradiciji), premise su uvijek opravdane a posteriori i zaključak mu je moguć. Rasuđivanje ide od partikularnog do generalnog. ${ }^{37}$ Kod ne-deduktivnog zaključivanja premise su plauzibilne, nisu istinite, i zaključak je plauzibilan. Rezoniranje ide od partikularnog prema partikularnom. ${ }^{38}$ Argument na temelju analogije - zaključivanje ide preko analogijskog odnosa, suprotno induktivnom ili deduktivnom odnosu. Dobar argument na temelju analogije jest onaj kod kojeg su sadržaj premisa i zaključka adekvatno povezani, tako da premise daju adekvatan dokaz za zaključak i premise su istinite, vjerojatne ili na drugi način pouzdane. ${ }^{39}$

Guarini pak pravi razliku između, kako on naziva, multy-sorce (case based) rasuđivanja (rasuđivanje utemeljeno na višestrukom izvoru ili slučaju), kao vrste source-blended argumenata

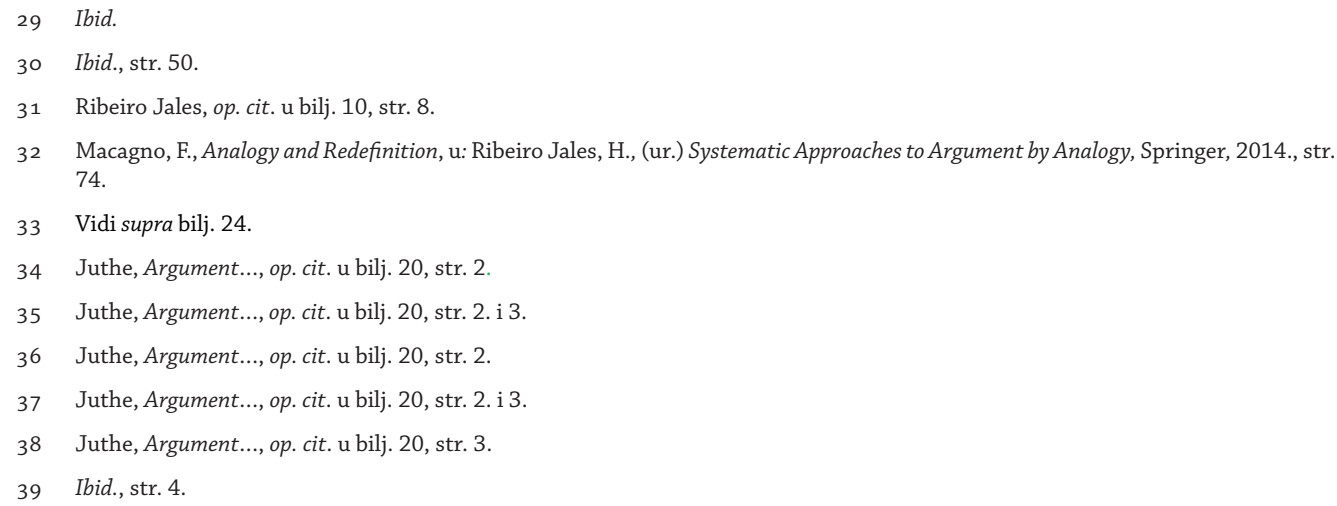


(argumenti koji uključuju kombinirane izvore), od drugih vrsta analogijskih argumenata. ${ }^{40}$ Ovi argumenti imaju neke sličnosti s onim što tradicionalno smatramo analogijskim argumentom, ali i značajne razlike. ${ }^{41}$ Ima više vrsta case-based rasuđivanja (rasuđivanja utemeljenog na slučaju). ${ }^{42}$ Rasuđivanje ovdje ide od slučaja prema načelu. Rasuđivanje koje ide od slučaja do slučaja počinje sa source case (slučaj od kojeg počinjemo rasuđivanje, na koji se pozivamo) i vodi ustanovljavanju jednog ili više stajališta o target case (slučaj o kojem rasuđujemo). Ova vrsta rasuđivanja često se naziva analogijskim i primjenjuje se u normativnim područjima, npr. pravu i etici, ${ }^{43}$ i uz sličnosti s analogijskim zaključivanjem, ima važne razlike u odnosu na njega. $\mathrm{U}$ većem dijelu literature smatra se da rasuđivanje ide od single source (pojedinačnog izvora) $\mathrm{k}$ single target (pojedinačnom cilju). Autor polazi od multiple sources (višestrukih izvora) prema single target (pojedinačnom cilju). Ovu vrstu analogije naziva djelomičnom analogijom. ${ }^{44}$

U odgovoru što su single source, a što multiple source argumenti, polazimo od sljedećeg: budući da je target (T) sličan source (S), S i T trebaju se tretirati na isti način. Ovo je single source analogijski argument. Druga forma analogijskog dokumenta postoji kada se onaj tko argumentira poziva na više od jednog je multi-source analogijski argument. ${ }^{45}$

Možemo praviti i distinkciju između same-domain analogije (analogija koja polazi iz iste domene) i different-domain analogije (analogija koja polazi iz različitih domena). ${ }^{46}$ Prvi slučaj je analogija gdje nisu samo odnosi između elemenata različitih objekata isti, nego su također i elementi iz istog područja. U drugom slučaju dva objekta pripadaju potpuno različitim područjima. ${ }^{47}$

Canale i Tuzet polaze od inferencijalističkog stajališta i smatraju da je analogijsko zaključivanje složeno i da obuhvaća tri inferencijalna koraka: abdukciju relevantnog svojstva P, indukciju vrste koje ima ovo svojstvo i dedukcija T (target) koje ima svojstvo Q. ${ }^{48}$ Zaključak je da T ima svojstvo Q budući da dijeli sa S (source) relevantno svojstvo P. ${ }^{49}$

Ima još varijanti analogijskog zaključivanja i analogije, ali smatramo da nekoliko navedenih stajališta dovoljno ilustrira složenost ovoga zaključivanja. ${ }^{50}$

\footnotetext{
40 Guarini, M., Understanding Blended Multi-Source Arguments from Partial Analogies, Ratio Juris, god. 23, br. 1, 2010., str. 65.

41 Loc. cit.

42 Loc. cit.

43 Ibid., str. 66.

44 Loc. cit.

45 Loc. cit.

46 Juthe, Argument..., op. cit. u bilj. 20, str. 5.

47 Loc. cit.

48 Canale, D., Tuzet, G., The A Simili Argument: An Inferentialist Setting, Ratio Juris, god. 22, br. 4, 2009., str. 499.

49 Canale, Tuzet, op. cit., str. 500.

50 Spomenimo još kvantitativnu i kvalitativnu koncepciju analogijskog zaključivanja, koje obuhvaćaju komunikativnu i nekomunikativnu upotrebu analogije; unutar komunikativne upotrebe nalazimo eksplanatornu i justifikatornu upotrebu, a unutar svake od njih klasifikatornu i ilustrativnu upotrebu, s jedne strane, a s druge strane, analogijske razloge i analogijsku osnovu (Bernejo-Luque, L., The Uses of Analogies, u: Ribeiro Jales, H., (ur.) Systematic Approaches to Argument by Analogy, Springer, 2014. str. 58. i dalje te, argument na temelju uvjerljive analogije (Juthe, Argument..., op. cit. u bilj. 20, str. 6.) i argument na temelju neuvjerljive analogije (ibid., str. 14.).
} 


\section{BITNA SLIČNOST I RATIO}

Najveći problem ovog argumenta jest, kako kod analogijskog zaključivanja općenito, tako i kod njegove upotrebe u pravu, karakterizacija svojstva relevantnosti. Odnosno, možemo upitati: kada je target case relevantno sličan source case? U pravnim stvarima standardan odgovor se odnosi na pojam ratio legis, ${ }^{51}$ ili, u sudskom kontekstu, ratio decidendi. ${ }^{52}$

Znači, kada se utvrdi da "razlog" zbog kojeg je norma regulirala izvjestan tip situacija na dani način (koji predstavlja njezin ratio legis) odgovara i situaciji koja nije regulirana, onda govori se da postoji sličnost za njezinu analognu primjenu. ${ }^{53}$ Određenje ratio je često težak i kontroverzan zadatak. ${ }^{54}$

U svakom slučaju sličnost nije "obična", već bitna sličnost, ${ }^{55}$ odnosno relevantna sličnost ${ }^{56}$ ili ona koja ima svrhu. ${ }^{57}$ Baš zbog potrebe ustanovljenja bitno sličnog odnosa u kojem se nalaze subjekti, a koji se može ustanoviti samo ciljnim i vrijednosnim rasuđivanjem, ovaj argument (na temelju analogije) ne može se držati formalnologički prinudnim. ${ }^{58}$

Rezoniranje na temelju analogije vrlo je blisko teleološkoj interpretaciji, u smislu da se u oba slučaja traži općenitija svrha pravila. Analogija se temelji na apstraktnijoj razini svrhe. Iako svrha pravila i opće načelo nisu isto, oni su na istoj metarazini, iznad ili iza pravila. ${ }^{59}$

Mogući odgovor jest, kako smo već naveli, ideja da je relevantno svojstvo temelj ratio legi$s a$, ili ratio decidendija u sudskom kontekstu. Naime, normotvorac kvalificira u normativnim terminima danu situaciju, npr. nešto je ili dopušteno ili zabranjeno ili obvezno, jer nešto ima svojstvo P'. Ako source ima svojstvo P' i - zbog ovoga - normativno svojstvo Q', trebao imati Q' ako dijeli sa source relevantno svojstvo P'. ${ }^{60}$

51 Za ratio legis kaže se da je to razlog donošenja pravnog akta (Pezo, V., Pravni leksikon, Leksikografski zavod Miroslav Krleža, Zagreb, 2007., str. 1379.). Inače, u pravnoj teoriji koristi se kod tumačenja i kod analogije. Ovdje se u određenim slučajevima traži identičan razlog donošenja određene norme (Pezo, op. cit., str. 1379.). Tako i: Visković, N., Teorija države i prava, 2. dopunjeno i izmijenjeno izdanje, Birotehnika CDO, Zagreb, 2006., str. 255.; Canale, Tuzet, op. cit. u bilj. 48, str. 507.; Vasić; Jovanović; Dajović, op. cit. u bilj. 21, str. 371.

ratio decidendi podrazumijeva se pak apstraktno pravno pravilo na kojem je sudac utemeljio svoju odluku u konkretnom slučaju (Pezo, op. cit., u bilj. 51, str. 1379.). Može postati mjerodavno (authorative) kao precedent za rješavanje drugih podudarnih slučajeva u sistemima utemeljenima na tradiciji common law. U američkom pravu označuje se obiter dicta (loc. cit.). U tome smislu: Damele, op. cit. u bilj. 11, str. 246.; Vasić; Jovanović; Dajović, op. cit. u bilj. 21, str. 371. Tako: Canale, Tuzet, op. cit. u bilj. 48, str. 499.

Tako: Visković, N., Argumentacija i pravo, Pravni fakultet Sveučilišta u Splitu, Split, 1997., str. 66. To, naravno, ne znači da se pri obrazlaganju pravnih odluka na temelju ovog argumenta (kao i ostalih koji se tradicionalno smatraju logičkim - a contrario, a fortiori) ne mora voditi računa o pravilima formalne logike. Poštovanje pravila formalne logike ima za cilj izbjegavanje pogrešaka u rasuđivanju i izvođenju neutemeljenih zaključaka (tako: Vrban, D., Država i pravo, Golden marketing, Zagreb, str. 471.). 
Ovo ukazuje da argument na temelju analogije nije kompletan argument. ${ }^{61}$ Treba neki komplementarni argument da opravda zaključak. Može zahtijevati da bude dopunjen najmanje sa: a) jednim argumentom koji opravdava zahtjev, da ondje gdje postoji praznina u pravu, ona može biti popunjena s pomoću analogije; b) s jednim ili s više argumenata koji opravdavaju zahtjev o ratio. Istina je da ratio može biti utvrđen na različitim stupnjevima općenitosti. H. Hart ${ }^{62}$ korektno je rekao da u svakom hard case različita načela podupiru komparirajuće analogije, i sudac često ima izabrati između njih, pouzdajući se, kao svjestan zakonodavac i što je prema njegovu mišljenju najbolje, a ne postoji ikakav utvrđen red prioriteta koji bi bili propisani za njega. ${ }^{63}$

Jedanput kada je ratio prihvaćen i opravdan, korektna upotreba argumenta na temelju analogije ne podrazumijeva diskrecijsku evaluaciju slučaja od strane suca ili suda. Korektna upotreba leži na nekoj temeljnoj (skrivenoj) presumpciji koja se tiče onoga što se uzima da je nužno prima facie za realizaciju svrhe zakona. U ovom pogledu argument na temelju analogije ovisi o tome kako se uzima od strane zajednice, ne o diskreciji ili preferencijama o moralnim vrijednostima zakonodavca, niti na diskreciji ili preferencijama suca. ${ }^{64}$

Korektna upotreba analogije je ako se primjenjuje na svrhu zakona, ali pogrešna ako se primjenjuje na ono što je nužno za realizaciju te svrhe. Jednostavno rečeno, korektna je ako se primjenjuje na ratio, ali pogrešno ako se primjenjuje na ono što je relevantno u svjetlu ratia. ${ }^{65}$

\section{RELEVANTNOST - FAKTIČNO I NORMATIVNO SVOJSTVO}

Dakle, kada je jedno svojstvo - npr. svojstvo P, relevantno za drugo svojstvo - npr. svojstvo Q? U kauzalnim kontekstima odgovor je relativno lagan: Svojstvo P je relevantno kada je kauzalno relevantno za svojstvo Q. ${ }^{66}$ Međutim, u pravnim stvarima argument na temelju analogije ima normativnu dimenziju. Naime, svojstvo Q nije faktično svojstvo, već normativno, deontičko svojstvo. Ako je tako, relevantnost svojstva $\mathrm{P}$ za normativno svojstvo Q ne može biti kauzalna vrsta relevantnosti. ${ }^{67}$ Pokažimo to na jednom slučaju analogijskog zaključivanju izvan prava (s kauzalnim svojstvom) i jednom slučaju analogijskog zaključivanja na pravnom primjeru (s normativnim svojstvom).

Primjer 1:

Džin tonik me opija (Q).

Džin tonik i votka tonik sadrže alkohol (P).

\footnotetext{
61 Canale, Tuzet, op. cit. u bilj. 48, str. 507. Iako navedeni autori koriste izraz "argument a simili", mi ćemo upotrebljavati u ovom radu uobičajeno nazivlje - argument na temelju (s pomoću) analogije.

62 Loc. cit.

63 Loc. cit.

64 Loc. cit.

65 Loc. cit.

66 Canale, Tuzet, op. cit. u bilj. 48, str. 500.

67 Ibid., str. 501.
} 
Prema tome, i votka tonik me opija (Q).

Dakle, svojstvo P je kauzalno relevantno za svojstvo Q. ${ }^{68}$

Primjer 2.

Bračnim partnerima je dopušteno da donose odluke o medicinskom tretmanu za partnera kojem nedostaje poslovna sposobnost (Q').

Bračni i istospolni partneri imaju bliski osobni odnos sa svojim partnerom ( $\left.\mathrm{P}^{\prime}\right)$.

Istospolnim partnerima je dopušteno da donose odluke o medicinskom tretmanu za partnera kojem nedostaje poslovna sposobnost (Q').

Dakle, ovdje je svojstvo Q' normativno. Osim toga, svojstvo P' nije kauzalno, već pragmatički relevantno, budući da se traži da opravda pripisivanje deontičkog svojstva Q'. Ali, u kojem smislu opravdanje? U kojem smislu imajući svojstvo P' može služiti kao opravdanje za pripisivanje svojstva Q'?69

\section{ZAKLJUČIVANJE NA TEMELJU ANALOGIJA U PRAVU}

Kao analogije karakteristične za pravo, navode se, a o kojima ćemo nešto reći: zakonska analogija (analogia legis, koja se uglavnom poistovjećuje $\mathrm{s}$ analogijom a simili), pravna analogija (analogija koja polazi od općih načela - analogia iuris), analogija inter legem i analogija na temelju precedenta.

Posebno se u tradiciji civilnog prava razlikuju dvije verzije analogije u pravu: zakonska analogija (analogia legis) i pravna analogija (analogia iuris). ${ }^{70}$ Analogia legis (ili a simili argument) shvaća se kao interpretativni argument koji se odnosi na primjenu pravne norme koja regulira bitno sličan slučaj za koji ne postoji pravna norma. ${ }^{71}$ Analogia iuris upotrebljava se za popunjavanje (pravnih) praznina gdje analogia legis ne predviđa rješenje. ${ }^{72} \mathrm{U}$ ovom slučaju analogija je ustanovljena prema tzv. "općim načelima prava, a ne prema pravnim normama te se još naziva "argument na temelju općih načela" ${ }^{73}$ Ta načela su izvedena iz "prirodnog prava" ili prava koja dijele "civilizirani narodi". ${ }^{74}$

68 Loc. cit.

69 Loc. cit.

70 Tarello, op. cit. u bilj. 70, str. 268.; Damele, op. cit. u bilj. 11, str. 243.; Zaccaria, G., Analogy as Legal Reasoning - The Hermeneutic Foundation, u: Nerhot, P., (ur.) Legal Knowledge and Analogy. Fragments of Legal Epistemology, Hermeneutics and Linguistics, Springer Science+Business Media, B. V., 1991., str. 55.; Maris, op. cit. u bilj. 16, str. 75.; Pezo, op. cit. u bilj. 51, str. 33.

71 U tome smislu, npr. Tarello, op. cit. u bilj. 70, str. 268.; Zaccaria, op. cit. u bilj. 70, str. 55.; Maris, op. cit. u bilj. 16, str. 75.; Pezo, op. cit. u bilj. 51, str. 33.; Visković, Argumentacija..., op. cit. u bilj. 58, str. 66.; Harašić, Ž., Sudska argumentacija, Pravni fakultet Sveučilišta u Splitu, 2010., str. 56.; Damele, op. cit. u bilj. 11, str. 243.

U tome smislu, npr. Tarello, op. cit. u bilj. 70, str. 268.; Zaccaria, op. cit. u bilj. 70, str. 55.; Maris, op. cit. u bilj. 16, str. 75.; Pezo, op. cit. u bilj. 51, str. 33.; Visković, Argumentacija..., cit. u bilj. 58, str. 81.; Harašić, Ž., Sudska..., u bilj. 71, str. 56.; Damele, op. cit. u bilj. 11, str. 243. 
Čitajući odluke hrvatskih sudova, upitali smo se poznaju li oni zakonsku i pravnu analogiju kao način popunjavanja pravnih praznina. Naime, kada primjenjuju analogiju kao način zaključivanja, ne spominju vrstu analogije, nego kažu da se (u slučaju nedostatka odredbe koja bi se primijenila na slučaj) analogno primjenjuje odredba. Iz toga zaključujemo da sudovi primjenjuju zakonsku analogiju i ne smatraju da je nedostatak odredbe koju bi direktno primijenili na slučaj - pravna praznina. S time se možemo složiti, jer je očito da unutar pravnog sistema postoji rješenje, odnosno odgovarajuća odredba. Što se tiče pravne analogije, skloni smo zaključiti da sudovi niti je poznaju, niti je primjenjuju. To što se sudovi pozivaju na načela, i to pretežno na procesna ili druga normirana načela, to ne znači da poznaju pravnu analogiju u gore navedenom, teorijski oblikovanom smislu, a još manje da njima popunjavaju pravne praznine. Da naši sudovi ne kažu (izričito ili prešutno) da postoje pravne praznine pozivamo se, među ostalim, na riječi jednog županijskog suca koji je rekao da kod nas nema "nekih" praznina te da u svakom slučaju postoji norma koja se može primijeniti.

Sada ćemo na dva primjera pokazati kako sudovi primjenjuju analogiju. Očito je, iako sudovi to ne kažu izričito, da je riječ o zakonskoj analogiji. Drugi primjer pokazuje i to da može biti tanka granica između onoga što smatramo zakonskom analogijom i onoga što podrazumijevamo pod pravnom analogijom.

U prvom primjeru tužiteljica je zatražila naknadu štete, jer je tuženi posjekao u mjestu M., na javnoj površini pod nadzorom tužiteljice, 28 stabala lipe koje su činile drvored, pri čemu su sva stabla bila velike starosti (neka i više od 100 godina). Prvostupanjski i drugostupanjski sud smatrali su da nema osnove da se visina štete utvrđuje primjenom kriterija prema Pravilniku o mjerilima za izradu šumskih odštetnih cjenika (Narodne novine, broj 41/1987), prema kojem se utvrđuje šumska šteta, jer da se, prema odredbama čl. 4. st. 2. Zakona o šumama, drvored ne smatra šumom. Nadalje citiramo: "Prema stajalištu ovog Vrhovnog suda, pogrešno je pravno shvaćanje prvostupanjskog i drugostupanjskog suda da se šteta u ovom slučaju sastoji i da je treba utvrditi isključivo prema vrijednosti posječenih stabala lipe izrađenih u trupce, uvažavajući pri tom ukupnu količinu dobivenih trupaca, strukturu po klasama i ukupnu vrijednost, o čemu se izjasnio vještak u svom nalazu i mišljenju...

Prema pravnom shvaćanju ovog Vrhovnog suda, budući da se u konkretnom slučaju radi o posjećenim stablima lipe, velike starosti, koja su činila drvored na javnoj površini mjesta M., štetu predstavlja, ne samo vrijednost posječenih stabala, dakle sama drvna masa, već ona sadrži i štetu koja je posljedica izvršene devastacije i gubitka opće korisne funkcije koja su posječena stabla imala.

Budući da se upravo navedeni kriteriji uzimaju o obzir i kod utvrđivanja šumske štete nema zapreka da se takav način utvrđivanja štete na odgovarajući načini, odnosno analogno primjeni i u ovom slučaju, neovisno o tome što drvored ne predstavlja šumu." 75

U drugom primjeru predmet spora u revizijskom stadiju postupka zahtjev je tužiteljice -majke koja je izgubila plod - zahtjev za naknadu nematerijalne štete za duševne boli zbog gubitka nerođenog djeteta. Prema zaključku drugostupanjskog suda - tužiteljica nama pravo na naknadu štete. 
"Naime, odredbom čl. 201. Zakona o obveznim odnosima ("Narodne novine”, broj 53/91, 73/91, 3/94, 7/96, 91/96 i 112/99 - dalje: ZOO) propisano je pravo na pravičnu naknadu za duševne boli zbog smrti člana uže obitelji. Ovaj sud nalazi pravilnim ocjenu suda prvog stupnja prema kojoj se ta odredba analogno primjenjuje i u slučaju gubitka ploda, tako da u konkretnom slučaju tužiteljici kao majci pripada pravo na pravičnu novčanu naknadu za pretrpljene duševne boli." 76

Pitamo se što da je sud smatrao da plod nije član uže obitelji? (Uostalom drugostupanjski sud je smatrao da majka nema pravo na naknadu štete.) Bi li tada došlo do primjene nekog pravnog načela?

Jednim aspektom zaključivanja na temelju argumenta analogije (argumenta a simili), kako smo istaknuli, držimo tzv. analogiju inter legem. O ovoj vrsti analogije ne govori se često. U teoriji kaznenog prava spominju je, i to kao jedini oblik dopuštene analogije. ${ }^{77} \mathrm{Za}$ analogiju inter legem karakteristično je da sam zakonodavac navodi na zaključivanje prema sličnosti, jer u samoj pravnoj odredbi, nakon navođenja situacija na koje se ona primjenjuje, na ostale mogućnosti upućuje oznakama npr. "naročito”, "na drugi način”, "ili druga osoba” i sl._Baš zato što se iznalaženje smisla zakona traži unutar zakona, ona je dopuštena u kaznenom pravu. Možemo reći da je zakonodavac, pri formuliranju pravnih odredaba koje navode na analogiju, namjerno ostavio praznine, odnosno riječ je o unutarnjim prazninama. ${ }^{78}$ Možemo se upitati, što da je sud ocijenio da nema odgovarajuće odredbe koja bi se primijenila (a vidimo da je drugostupanjski sud ocijenio da tužiteljica nema pravo na naknadu štete), bi li onda u obzir došla primjena nekog pravnog načela.

U ostalim slučajevima u kaznenom pravu analogija je zabranjena. ${ }^{79}$ Zabranjena je ako se njome na temelju sličnosti s postojećim djelima stvaraju nova kaznena djela ili pooštravaju postojeća. ${ }^{80}$ Osim toga ona je u suprotnosti s načelom zakonitosti, koje se ovdje izražava kao nullum crimen sine lege stricta. ${ }^{81}$

Kao primjer analogije inter legem dajemo sljedeći primjer:

U izreci stoji da je počinitelj oglašen krivim jer je "u namjeri da dođe do pokretnih stvari, i novca, naglim trzajem otvorio desna vrata na zaključanom osobnom vozilu marke Zastava 750, vlasništvo A. R., a kako druge stvari nije našao, iz istog je uzeo i zadržao za sebe jednu deku žuto-smeđe boje vrijednosti oko 400,00 hrvatskih dinara".

Sud počinitelja oglašava krivim za kazneno djelo teške krađe iz odredbe čl. 131. st. 1. t. 1. KZH-a, koja glasi: "Počinitelj djela krađe (članak 125.) kaznit će se (...), ako je krađa počinjena: 1) obijanjem, provaljivanjem ili drugim svladavanjem većih prepreka da se dođe do stvari

76 VSRH, Rev 1446/1988 od 26. ožujka 2003. Izbor odluka 1/2003.

77 Tako npr.: Grozdanić,V.; Škorić, M.; Martinović, I., Kazneno pravo. Opći dio, Pravni fakultet Sveučilišta u Rijeci, Rijeka, 2013. str. 56.; Horvatić, Ž.; Derenčinović, D.; Cvitanović, L., Kazneno pravo. Opći dio 1. Kazneno pravo i kazneni zakon, Pravni fakultet Sveučilišta u Zagrebu, Zagreb, 2016., str. 137.; Novoselec, P., Opći dio kaznenog prava, 5. izmijenjeno izdanje, Sveučilište J. J. Strossmayera u Osijeku, Osijek, 2016., str. 54.

78 Pavčnik, M., Argumentacija v pravu, GV Založba, 3. izdanje, Ljubljana, 2013., str. 166.

79 Tako npr.: Pezo, op. cit. u bilj. 51, str. 33.; Grozdanić, op. cit. u bilj. 77, str. 56.; Horvatić, op. cit. u bilj. 77, str. 135.-137.; Novoselec, op. cit. u bilj. 77, str. 53.

$80 \quad$ Pezo, op. cit. u bilj. 51, str. 33; Grozdanić, op. cit. u bilj. 77, str. 56.

81 Loc. cit. 
iz zatvorenih zgrada, soba, blagajna, ormara i drugih zatvorenih prostora." Nalazimo da je sudac primijenio analogiju (inter legem), jer je pod "drugim zatvorenim prostorom" smatrao automobil..$^{82}$

\section{PRECEDENT I ANALOGIJA}

U vezi s pitanjem odnosa između analogije i precedenta postoje dva stava: prvi, da je analogija način zaključivanja koji se (kao najpogodniji), javlja kod precedenata u common law sistemima; ${ }^{83}$ i drugi, da su argument iz precedenta i argument na temelju analogije dva oblika rasuđivanja u common law sistemima. ${ }^{84}$ Prema zastupljenijem, drugom stajalištu, kaže se da precedent uključuje raniju odluku koja je slijeđena u kasnijem slučaju zbog toga što su oba slučaja "ista" (same). Analogija pak uključuje raniju odluku koja je slijeđena u kasnijem slučaju zbog toga što je kasniji slučaj "sličan" (similar) ranijem. ${ }^{85}$ Glavni filozofijski problemi koji proizlaze iz precedenta i analogije su ovi: prvo, kada su dva slučaja "ista" u svrhu precedenta, drugo, kada su dva slučaja "slična" u svrhu analogije, i treće, u obje situacije, zašto bi odluka iz ranijeg slučaja pogađala odluku u kasnijem slučaju. ${ }^{86} \mathrm{U}$ čemu se razlikuje rasuđivanje iz precedenta i rasuđivanje iz analogije? Sumarno, to možemo opisati na sljedeći način. Precedent je odluka suda koja ima specijalno pravno značenje, a koje proizlazi iz toga što se smatra da ona ima i teorijski i praktički autoritet. ${ }^{87}$ Odluka ima teorijski autoritet, ako postoje dobri razlozi za vjerovanje da je raniji slučaj korektno odlučen, i da su činjenice kasnijeg slučaja iste kao one u ranijem. Tada postoje dobri razlozi za vjerovanje da će ista odluka biti korektna u kasnijem slučaju. ${ }^{88}$

Precedenti pak imaju praktični autoritet jer se smatraju dijelom stvaranja prava. Nešto što je sud utvrdio jest, jer je sud tako utvrdio. Jedna važna posljedica praktičkog autoriteta precedenta proizlazi iz toga što je sud vezan primijeniti pravo i što ranije odluke imaju praktični autoritet iznad sadržaja prava, kasniji sudovi su vezani slijediti odluke u ranijim slučajevima. Ovo je poznato kao doktrina precedenta ili stare decisis. ${ }^{89}$

Može se primijetiti da moderni common law podržava jaku verziju stare decisis, što opisujemo na sljedeći način. Zahtijeva se da kasniji sudovi slijede ranije odluke čak i onda ako su ovi slučajevi, prema prethodno postojećem pravu, krivo odlučeni. Dakle, doktrina stare decisis zahtijeva da kasniji sudovi budu vezani ovim pogrešnim odlukama. Ovo, jer postoji presumpcija da u svakom slučaju postoji barem jedna pravno korektna posljedica, a drugi ishodi mogu biti pogrešni. Što pak znači da su dva slučaja ista - to znači da su činjenice u kasnijem slučaju iste

82 K 56/91, Županijski sud u Požegi, 29. listopada 1992.

83 Npr. Farrar, op. cit. u bilj. 14, str. 148.

84 Npr. Lamond, op. cit. u bilj. 11. Inače, mišljenje je autora ovog rada da je ovo drugo stajalište zastupljenije, budući da većina autora ne kaže izričito koje stajalište zastupa.

85 Lamond, op. cit. u bilj. 11.

86 Lamond, op. cit. u bilj. 11.

87 Lamond, op. cit. u bilj. 11, t. 2.

88 Lamond, op. cit. u bilj. 11, t. 2. 
kao one u ranijem slučaju. Ako kažemo da su dva slučaja ista, ne znači i da su identični. Preciznije, dva slučaja su ista "u svim relevantnim aspektima". A onda se i može postaviti daljnje pitanje što čini dva slučaja "relevantno" istim. ${ }^{90}$

U vezi s ovom materijom važno je razlikovati ratio decidendi i obiter dicta. Ratio decidendi je obvezujuće za buduće slučajeve, dok obiter dicta predstavlja druge tvrdnje i iskazana stajališta u presudi koje nisu obvezujuće za kasnije sudove. Sa stajališta precedenta važan je ratio. ${ }^{91}$

Analogija je argument koji polazi od toga da slučaj treba biti tretiran na određeni način zato što postoji sličan slučaj koji je već tretiran. ${ }^{92}$ Snaga argumenta na temelju analogije i precedenta je različita. Precedent mora biti slijeđen čak i onda ako sud ima moć odbiti raniju odluku i učini to. Argumenti na temelju analogije variraju u svojoj snazi, ali analogije ne obvezuju. ${ }^{93}$

Analogija se više upotrebljava u angloameričkom, nego kontinentalno-europskom sistemu. Name, ovaj posljednji sistem je prilično potpun i kodificiran, i zato je kod njega manja potreba za analogijom..$^{94}$

\section{POJAM I BROJNOST PRAVNIH PRAZNINA}

Pojam pravnih praznina vrlo je prijeporan. ${ }^{95}$ Uobičajeno se razlikuju tri shvaćanja pravnih praznina. Mi pod pravnom prazninom podrazumijevamo jedan važan i konfliktan društveni odnos koji nije uređen pravnim normama, a zbog svoje važnosti trebao bi biti. ${ }^{96}$ Kao drugo shvaćanje navodimo tehničke pravne praznine: pravni odnosi su normirani, ali tehnički nedostatno (zbog npr. nedostajanja nekog važnog elementa norme). ${ }^{97} \mathrm{U}$ slučaju vrijednosnih pravnih praznina postoji stav nekih subjekata da norma uređuje određeni društveni odnos vrijednosno manjkavo, prije svega nepravedno. ${ }^{98} \mathrm{U}$ ova dva posljednja značenja nismo istraživali postojanje pravnih praznina, jer su u jednom slučaju odnosi ipak normirani, a u drugom, subjektivni stavovi raznih tumača (pa tako i sudaca) o (ne)postojanju praznina, mogu biti različiti u istom slučaju.

90 Lamond, op. cit. u bilj. 11, t. 2.

91 Lamond, op. cit. u bilj. 11, t. 2.1.

92 Lamond, op. cit. u bilj. 11, t. 4.

93 Lamond, op. cit. u bilj. 11. t. 4.

94 Vrban, op. cit. u bilj. 58, str. 465.

95 I Bobbio kaže da problem pravnih praznina postaje povijesno relevantan od onog trenutka u kojem je pravni izvor, odnosno zakon nadmašio sve druge, tako da zakonodavci zastupaju stav da su njihove tvorevine dovoljne za rješavanje svih sadašnjih $i$ budućih sporova (Bobbio, N., Lacune del diritto, u: Comanducci, P., Guastini, R., (ur.) L'analisi del ragionamento giuridico, vol. II, Giappichelli, Torino, 1989., str. 189.

96 Visković, Teorija..., cit. u bilj. 51, str. 260. Comanducci drži da se problem pravne praznine, gledajući sa stanovišta suca, javlja onda kada sudac drži da određeno ponašanje, relevantno za slučaj koji mora riješiti, nije određeno od strane zakona niti kao zabranjeno, niti obvezno, a niti kao dopušteno (Comanducci, P., Sulle lacune: note in margine a Bobbio, u: Comanducci, P., Guastini, R., (ur.) L'analisi del ragionamento giuridico, god. 2, Giappichelli, Torino, 1989., str. 211.

97 Visković, Teorija..., cit. u bilj. 51, str. 236. Guastini smatra da postoji tehnička praznina u poretku kada u njemu nedostaje norma čije je postojanje nužan uvjet sposobnosti djelovanja neke druge norme. Guastini, R., Sintaksa prava (s talijanskog preveo L. Burazin), Naklada Breza, Zagreb, 2016., str. 373. 
U kojoj se mjeri pred tumačima, ponajprije sucima, javljaju pravne praznine? Odgovor možemo dati i s aspekta teorije prava, ali i s aspekta pravne prakse. Iako postoje razlozi da se prije odgovori s aspekta teorije (jer ona, u pravilu, postavlja teme, hipoteze i dr. pravnoj praksi), dajemo odgovor najprije s aspekta pravne prakse. U knjizi "Sudska argumentacija” iz 2010. izvršili smo istraživanje o zastupljenosti pojedinih argumenata u odlukama hrvatskih sudova, pa tako i argumenta a simili (koji se uglavnom poistovjećuje sa zakonskom analogijom (analogia legis) i argumenta koji polazi od općih načela prava (analogia iuris). ${ }^{99}$ Našli smo upotrebu analogije u vidu tzv. analogije inter legem (samo u odlukama iz kaznenog prava) i upotrebu pravnih načela, za koje slučajeve ne možemo reći da predstavljaju upotrebu argumenta analogia iuris. ${ }^{100}$ U svrhu ovog rada izvršili smo još jedno manje istraživanje, tako da smo među građanskim odlukama Vrhovnog suda ${ }^{101}$ ciljano tražili upotrebu analogije, i našli smo slučajeve zakonske analogije (analogia legis).

U teoriji postoje shvaćanja o brojnosti pravnih praznina. Tako je, primjerice, poznat Kantorowitzev stav da praznina ima koliko i riječi zakona. ${ }^{102}$ Vasić pak smatra da pravne praznine ne samo što postoje, nego se zbog prirode prava nužno pojavljuju. Ističe da je to nužno s jedne strane, zbog propusta zakonodavca da općim normama regulira sve aspekte nekog odnosa i sa svim njegovim osobitostima te zato što zakonodavac ne može predvidjeti budućnost i svaku promjenu koja se u nekom odnosu događa ili da nasluti nove odnose koji će se tek pojaviti. ${ }^{103}$ Slično i Visković koji kaže da se polazi od toga da pravo teži potpunom obuhvatu odnosa koji su njegov predmet i koji su važni za opstanak društva, sadrže snažne sukobe interesa i izvanjski su kontrolabilni, ali zbog njihove složenosti, dinamičnosti i promjenljivosti to u svim slučajevima ne uspijeva, pa društveni odnosi ostaju nenormirani ili nedostatno normirani. ${ }^{104}$

Perelman postavlja pitanje može li biti riječ o praznini ne samo kad zakon šuti, nego i onda kada je nejasan. ${ }^{105}$ Time Perelman otvara pitanje razlikovanja tumačenja (kad je zakon nejasan) i popunjavanja praznina (kad zakon šuti). Ono se većinom razrješava tako da se kaže da tumačenje pretpostavlja da za slučaj, o kojem treba odlučiti, postoji pravna odredba, dok, naprotiv, popunjavanje praznina pretpostavlja da za slučaj nije predviđena odredba, ${ }^{106}$ pa tada treba upotrijebiti neko pravno načelo.

Ovo pitanje se može razmatrati i sa sljedećeg aspekta. Stav koji ide od toga da se popunjavanje pravnih praznina odvaja od tumačenja, polazi od toga da su granice tumačenja granice teksta norme. Značenje koje bi se pridalo nekoj normi, a koje je jezično neodrživo, nije znače-

99 Istraživanje je izvršeno u knjizi Harašić, Ž, Sudska argumentacija, Pravni fakultet Sveučilišta u Splitu, Split, 2010. Istraživanje je obuhvatilo 388 odluka iz posljednjih deset godina prošlog stoljeća, i to iz građanskog, trgovačkog, kaznenog i upravnog prava, u svim stupnjevima koji čine jedan spis (npr. u području građanskog prava pretražili smo u jednom spisu odluku općinskog suda, odluku županijskog suda, i odluku Vrhovnog suda Republike Hrvatske.

Naime, suci su se pozivali na pravna načela, ali nisu naveli da postoji pravna praznina. Osim toga, većina načela na koja su se pozivali čine tzv. normirana načela, pa su se pozivanjem na njih pozivali i na pravne odredbe - vidi infra, t. 10.

101 Vrhovni sud Republike Hrvatske, Izbor odluka, građansko i građansko procesno pravo, 1993. do 2011.

102 Pokrovac, Z., H. U. Kantorowitz i slobodnopravni pokret, doktorska disertacija, Split, $1995 .$, str. 264.

103 Vasić; Jovanović; Dajović, op. cit. u bilj. 21, str. 367.

104 Visković, op. cit. u bilj. 58, str. 234

105 Perelman, Ch., Pravo, moral i filozofija, Nolit, Beograd, 1983., str. 134.

106 Tako npr. La Torre, M.; Pattaro, E.; Taruffo, M., Statutory Interpretation in Italy, u: MacCormick, N. D., Summers, R. S., (ur.) Interpreting Statutes, Aldershot (etc.), 1991., str. 218.; Vrban, op. cit. u bilj. 58, str. 461.; Vasić; Jovanović; Dajović, op. cit. u bilj. 21, str. 367. 
nje do kojeg se dolazi tumačenjem prava. Pri popunjavanju pravne praznine sudac se ne drži teksta norme, već izlazi iz njegova okvira i daje novu: pri tumačenja on daje značenje norme. ${ }^{107}$ Tako i Zaccaria kaže da argument na temelju analogije ima produktivnu funkciju i ima učinak normativne invencije kroz nalaženje i formuliranje nove norme, i širi deskriptivni opis subjekta ili vrste subjekata u danoj odredbi i uključuje subjekte ili vrste subjekata koji nisu striktno jezično pokriveni, ali su "slični". ${ }^{108}$ Osim toga, sudac uvijek tumači pravo, ali ne mora i popunjavati pravne praznine, a nekad i ne smije, kao npr. u kaznenom pravu. ${ }^{109}$

Guastini pak smatra da kako bismo izbjegli pravnu prazninu i riješili slučaj, vjerojatno bismo trebali protumačiti normativni tekst, tj. vratiti se tekstu i protumačiti ga drukčije. ${ }^{110}$ Odnosno, smatra da se praznine na neki način tumačenjem proizvode te kao što se proizvode, tako ih se može i izbjeći ili spriječiti. ${ }^{111}$

Moguće je, kako navodi Perelman, da u pravnim sustavima postoji kolebanje, pa ono što jedan sustav smatra tumačenjem, u drugom može biti kvalificirano kao popunjavanje praznine. ${ }^{112}$

\section{POJAM PRAVNIH NAČELA}

Sada treba nešto reći o pravnim načelima, jer se njima, u nekim slučajevima, popunjavaju pravne praznine, tj. kada se u slučaju postojanja reguliranog i nereguliranog odnosa, na ovaj drugi slučaj ne može primijeniti pravna norma (odredba), jer je nema - onda se mora primijeniti pravno načelo.

Smatramo da za potrebe ovog rada, a u svrhu odgovora što su pravna načela, ne moramo ulaziti u detaljnu raspravu o odnosu pravnih načela i normi, budući da polazimo od toga da su pravna načela jedna vrsta općih, i to najviših pravnih normi. Ipak ćemo spomenuti da se većina radova koja tematizira odnos između načela i normi i dalje poziva na Dworkinova stajališta izražena prije svega u glasovitom djelu Taking Rights Seriously. ${ }^{113}$ Dworkin pravna načela i pravne norme promatra kao vrste pravnih standarda na temelju kojih suci donose svoje odluke i između kojih je razlika samo formalna: norme se primjenjuju prema načelu sve ili ništa: ako postoje činjenice predviđene normom, tada norma važi te se u tom slučaju rješenje koje nudi mora prihvatiti, ili ne važi te tada uopće ne pridonosi odluci. ${ }^{114}$ Osim toga, za razliku od pravnih načela koja mogu biti u sukobu, pravne norme ne mogu. Ako je to ipak slučaj, onda jedna od njih ne važi. ${ }^{115}$

\footnotetext{
107 Vasić, Jovanović, Dajović, op. cit. u bilj. 21, str. 371.

108 Zaccaria, op. cit. u bilj. 70, str. 57.

109 Vidi supra, t. 8.

110 Guastini, op. cit. u bilj. 97, str. 369.

111 Guastini, op. cit. u bilj. 97, str. 370.

112 Perelman, op. cit. u bilj. 105, str. 135.

113 Dworkin, R., Taking Rights Seriously, Duckworth, Cambridge, 1977.

114 Dworkin, R., op. cit. u bilj. 113, str. 24.

115 U slučaju da su pravna načela u sukobu, tada je za razrješenje tog sukoba potrebno uzeti u obzir "relativnu težinu" svakog načela (Dworkin, R., op. cit. u bilj. 113, str. 26.).
} 
Prema Alexyjevoj utjecajnoj teoriji - temeljna prava, sadržana u njemačkom Ustavu, mogu se razumjeti kao načela i upravo temeljna prava služe kao paradigmatski slučajevi načela. Načela se pak mogu razumjeti kao optimizacijski zahtjevi. ${ }^{116}$

I Alexyjeva i Dworkinova teorija načela kažu da u pravu postoje dvije vrste normi: pravila i načela. Pravila ne prave poseban problem, jer ona mogu biti primijenjena supsumpcijom, dok su načela interesantnija, i mogu biti primijenjena balansiranjem s drugim načelima i normama. ${ }^{117}$ Načela se balansiraju s pomoću optimizacije u slučajevima u kojima kolidiraju. ${ }^{118}$ Polazi se od logičke teze da se pravila i načela razlikuju samo u formalnoj strukturi. ${ }^{119}$

Ralf Poscher kritizira ovu doktrinu o pravnim načelima: prvo, kritizira je kao pravnu teoriju, kada pravi razliku između pravila i normi, te (on) tvrdi da pravna načela nemaju nužno optimizacijske zahtjeve kao sadržaj; drugo, kritizira je kao metodologijsku teoriju, onda kada reducira (pre)suđenje na sumpsumciju i balansiranje, ${ }^{120}$ iako dopušta da načela imaju određenu ulogu u suđenju i pravnoj argumentaciji. Osim toga, približava se našem stavu da su načela određene temeljne i u mnogim slučajevima općenitije norme nego druge. ${ }^{121}$

Nekada kažemo "pravna načela”, a nekada “opća pravna načela”. U čemu se razlikuju pravna načela među sobom? Ako postoje opća načela prava, što su to posebna pravna načela? Ne pojednostavnjujući problem, smatramo da su načela uvijek opća, bez obzira na to koristimo li ili ne u njihovu nazivu pridjev "opći”. Naime, ona su opća bilo da se odnose na pravo u cjelini, bilo da se odnose na pravo konkretnog pravnog sistema. Složili bismo se s tvrdnjom da se sadržaj pravnih načela razlikuje od sistema do sistema. ${ }^{122} \mathrm{Na}$ jedan aspekt problema ukazuje nam i sam Tarello. On smatra da se rasprava o prirodi, vrijednosti i upotrebi pravnih načela naročito razvila od izlaženja spomenutog Dworkinova djela te se otada manje upotrebljava tradicionalni termin "opća načela prava", a više se govori o "pravnim načelima". ${ }^{123}$ Kakvo je značenje pravnih načela u stvarnom odlučivanju? Dworkin im pridaje veće značenje te drži da ako je sudac dovoljno britak, može i u slučajevima kada ne postoji pravna norma koja bi se primijenila na konkretan slučaj (u tzv. hard cases) uvijek iznaći pravno načelo i tako riješiti slučaj. ${ }^{124}$ Značajnu ulogu pravnim načelima daju i La Torre, Pattaro i Taruffo, koji drže da posljednjih godina o argumentu koji polazi od općih pravnih načela pravni teoretičari vjerojatno najviše diskutiraju (u odnosu na druge argumente), zahvaljujući novom razvoju prava u industrijskim društvima. Smatraju da je pravo dobilo zadatke koje su prije preuzimale druge društvene institucije (poput obitelji) ili koji uopće nisu bili shvaćeni kao "zadaci" (npr. zaštita prirodne okoline). Pravo se manje uzima kao formalni okvir za akciju koju bi poduzimali pojedinci, a

116 Poscher, R., Insights, Errors and Self-Misconceptions of the Theory of Principles, Ratio Juris, god. 22, br. 4, 2009., str. 426.

117 Poscher, op. cit. u bilj. 116, str. 426.

118 Loc. cit.

119 Poscher, op. cit. u bilj. 116, str. 449.

120 Loc. cit.

121 Loc. cit.

122 Summers, R. S., Taruffo, M., Interpretation and Comparative Analysis, u: MacCormick, N. D., Summers, R. S., (ur.) Interpreting Statutes, Aldershot (etc.), 1991., str. 468.

123 Tarello, op. cit. u bilj. 70, str. 269. Isti navodi kako je prvobitnu upotrebu izraza analogia iuris otkrio Bobbio.

124 Takvog suca, koji u svakom spornom slučaju može pronaći načelo Dworkin naziva Herculesom (Dworkin, op. cit. u bilj. 113, naročito str. 105.-130.). 
više kao instrument da se postignu specifični ciljevi. Rasprava o pravu nije više o "formi”, nego o "ciljevima", "politikama" i "načelima" i o tome koje od njih preferiramo više, a koje manje. ${ }^{125}$ Tarello pridaje manju ulogu pravnim načelima, i kaže da pravna načela imaju malu operativnu moć zbog neslaganja o njihovoj prirodi i o sadržaju. ${ }^{126}$ Tako on ističe da je sve do prve polovine 20. stoljeća moderna doktrina u kontinentalnoj Europi vodila rasprave o tome je li riječ o načelima "prirodnog prava”, ili o načelima "prava svojstvenog svim civiliziranim narodima" ili o načelima izvedenim iz cjeline svih odredaba jednog pozitivnog prava. ${ }^{127}$

$\mathrm{Na}$ kraju rasprave o pravnim načelima dajemo svoju definiciju: pravna načela su najviše norme pravnog sustava koje izražavaju temeljne vrijednosti, stoga s njima moraju biti usklađene i tumačene sve ostale pravne norme. ${ }^{128}$

\section{NEKE VRSTE PRAVNIH NAČELA}

Prvo ćemo spomenuti normirana načela. Naime, velik broj (općih) načela danas više nije samo izraz pravne znanosti i pravne prakse, nego je i normiran, tj. ušao je u pravne norme kao njihov sadržaj. Mnoga od njih su sadržana u ustavu, u odredbama koje određuju postupanje u kaznenim, građanskim i upravnim postupcima te mnogim normama materijalnog prava. ${ }^{129}$

Kako smo već naveli, čini nam se, da kod argumenta (općih) načela, u istraživanju objavljenom 2010., nema slučaja uporabe tog argumenta koji bi predstavljao popunjavanje pravnih praznina. Nalazimo da je razlog tome upravo to što su sva načela na koja se pozivaju sudovi iz istraživanog uzorka kodificirana, tj. da su ušla u sadržaj pravnih odredaba. Stoga se sudovi, pozivajući se na neko pravno načelo, pozivaju na pravnu odredbu u kojoj je to načelo sadržano.

Nadalje navodimo specifična i nespecifična načela. Opća načela prava imaju veliku ulogu u interpretaciji, prvenstveno zbog toga što, smatramo, izražavaju temeljne vrijednosti s kojima moraju biti u skladu i prema kojima se moraju tumačiti sve ostale pravne norme. Zato se koristi i termin "vrijednosna načela". ${ }^{130}$ Visković polazi od toga da su vrijednosna načela temeljni preskriptivni izrazi osnovnih ljudskih potreba koje svaki pravni poredak mora regulirati, ${ }^{131}$ te razlikuje dva osnovna tipa pravnih vrijednosti: one koje su specifične za pravo - pravednost, mir, zakonitost, pravna sigurnost te potpunost i koherentnost sustava pravnih normi i one koje nisu specifične

125 La Torre, M.; Pattaro, E.; Taruffo, M., op. cit., u bilj. 106, str. 223.

126 Tarello, G., op. cit., u bilj. 74, str. 270.

127 Loc. cit.

128 Visković, Teorija... cit. u bilj. 51, str. 252. I Van Hoecke kaže da su načela norme koje su izražene u općim terminima, imaju široko područje primjene i izražavaju vrijednosti koje su temeljne za pravni sistem ili njegove dijelove (Van Hoecke, M., Law as Communication, Hart Publishing, Oxford-Portland, Oregon, 2002., str. 160.).

129 Pokazat ćemo to na procesnim načelima postavljenim u hrvatskom Ustavu. Tako Ustav Republike Hrvatske (Narodne novine, broj 56/1990, 135/1997, 8/1998, 113/2000, 124/2000, 28/2001, 41/2001 41/2001, 55/2001, 76/2010, 85/2010, 5/2014) navodi sljedeća procesna načela: načelo zakonitosti (čl. 5. i čl. 118./3), neovisnosti (čl. 115./2), jednakosti pred sudovima (čl. 26.), javnosti (čl. 117.), načelo pravne pomoći (čl. 27.), presumpcija nevinosti (čl. 28.), pravo na pravično suđenje (čl. 29.), pravo na pravni lijek (čl. 18.), načelo nepokretnosti sudaca (čl. 123./3).

130 Visković, Argumentacija..., cit. u bilj. 58, str. 60. i dalje; Miličić, V., Metodologija prava - Nomotehnika, Sveučilišna tiskara: Pravni fakultet, Zagreb, 1998., str. 41. i dalje.

131 Visković, Argumentacija..., op. cit. u bilj. 58, str. 60. 
za pravo, u odnosu na koje su ove prve instrumentalne - život i zdravlje, sloboda, osobna sigurnost, obitelj, istina, rad, imovina, obrazovanje, promet dobara, privatnost itd. ${ }^{132}$

Aarnio, koji shvaća sudačku aktivnost kao kreaciju, među argumente na kojima sudac može temeljiti svoje odluke, ubraja i opća pravna načela te spominje dvije vrste načela. Prva su načela koja izražavaju temeljne ideološke vrijednosti pravnog sistema, kao npr. načelo vladavine prava (rule of law), načelo privatnog vlasništva, moralna načela na kojima se temelji pojam obitelji i pretpostavku razumnog zakonodavca. ${ }^{133}$ Druga su vrsta opća pravna načela koja su integrirana u važeće pravo. Njih pak dijeli na: a) formalno valjana načela, kao što su temeljna prava sadržana u ustavu, načelo jednakih dijelova u nasljednom pravu, načelo zaštite radnika u radnom pravu, načelo dobre vjere u ugovornom pravu; b) pravne generalizacije, pod kojima podrazumijeva opća pravna načela stvorena kroz pravnu indukciju i heuristiku, kao npr. načelo pacta sund servanda i načelo poštenja u ugovornom pravu. Ona nisu izričito inkorporirana u pravo, ali nalaze izvjesni temelj u drugim, formalno važećim pravnim odredbama, primjerice načelo audiatur et altera pars i načelo zakonitosti u kaznenom pravu. ${ }^{134}$

Summers i Taruffo smatraju da se u većini pravnih sistema mogu naći pravna načela koja se razlikuju u najmanje tri vida: 1) materijalne moralne norme na koje se pozivaju suci kad interpretiraju zakon ili inače, npr. načelo da nijedna osoba ne može imati koristi iz vlastite pogreške; 2) opće propozicije materijalnog prava široko primjenjive unutar određene grane prava, npr. nulla poena sine lege u kaznenom pravu, načelo da nema odgovornosti bez krivnje u deliktnom pravu, dobra vjera u ugovornom pravu; 3) opće pravne propozicije, materijalne i proceduralne, široko primjenjive u čitavom pravnom sistemu, npr. materijalna načela koja štite pravo na slobodu udruživanja i govora te slobodu od diskriminacije na rasnim ili vjerskim temeljima. ${ }^{135}$

Perić razlikuje tri kategorije pravnih načela. Prvu vrstu načela naziva općim načelima prava. Pod njima razumijeva ona načela što su se pojavila tijekom pravne povijesti i zadržala sve do danas, posebno kod onih naroda koji su imali uočljiv stupanj pravnog razvoja. "Takva su načela duboki sediment pravnog iskustva i umijeća, pravne filozofije i logike, ona su najvrednija riznica - blago pravnog razmišljanja i zaključivanja." ${ }^{136}$ Smatra da bi se moglo reći da su ona, jer su nataložena pravna mudrost kroz vjekove, čak iznad svih drugih pravnih načela. Često se nazivaju Dicta et regulae iuris. Druga načela naziva općim načelima konkretnog pravnog sustava i poretka jedne konkretne države. Pod njima podrazumijeva sva ona načela što su redovito navedena u temeljnoj pravnoj grani svakog pravnog sustava - ustavnom pravu. Nalazi da su to u hrvatskom pravnom sustavu: ravnopravnost građana, slobode i prava građana, pravo na rad i rezultate rada, načelo solidarnosti, zakonitosti, demokracije itd. Treća vrsta načela su osnovna načela na kojima je utemeljena pojedina grana prava pojedinog pravnog sustava. ${ }^{137}$

Van Hoecke ističe jednu kategoriju načela koja su izričito postavljena u zakonicima, od kojih neka imaju dugu doktrinarnu tradiciju i izražena su u maksimama, često na latinskom.

132 Visković, N., Pojam prava, 2. dopunjeno i izmijenjeno izdanje, Logos, Split, 1981, str. 105. i dalje.

133 Aarnio, A., Statutory Interpretation in Finland, u: MacCormick, N. D., Summers, R. D., (ur.) Interpreting Statutes, Aldershort (etc.), 1991., str. 142.

134 Ibid., str. 143

135 Summers, Taruffo, op. cit. u bilj. 122, str. 468.

136 Perić, D., Država i pravni sustav, 6. izd., Informator, Zagreb, 1994., str. 181.

137 Perić, Država..., op. cit. u bilj. 136, str. 181. 
Jedno takvo načelo koje je postavljeno u zakonskoj odredbi, a poznaje ga većina pravnih sistema jest in dubio pro reo. Neka od njih se temelje na praktičnom iskustvu i predstavljaju vodiče u interpretaciji i primjeni prava, kao npr. mater sempre certa est ili interpretatio cessat in claris. ${ }^{138}$

Nalazi da od druge polovine 20. stoljeća kontinentalno-europski sudovi primjenjuju i nepisana pravna načela, koja koriste za popunjavanje praznina u pravu ili za ispravljanje zakonskog prava, prihvaćajući ih kao izvor prava. To su opća pravna načela (general principles of law). ${ }^{139}$

Van Hoecke razlikuje dva tipa nepisanih pravnih načela koja upotrebljavaju sudovi. S jedne strane to su ona koja bi se mogla nazvati "implicitna" ili "strukturna", a izvedena su, ili se barem zahtijeva da budu izvedena, iz pisanog prava. Tako npr. načelo "dobre vjere”, načelo pacta sunt servanda, zabrana ekonomske diskriminacije i načelo ekonomske slobode. ${ }^{140} \mathrm{U}$ izvjesnom smislu strukturna načela skriveni su aksiomi logičke strukture pravnog sistema ili nekih njegovih grana. Njihovo prihvaćanje nužno je ili barem poželjno za (optimalnu) koherentnost pravnog sistema. Ova načela implicitno su prisutna u pravnom sistemu, čak i kad ih zakonodavac nije svjestan. ${ }^{141} \mathrm{~S}$ druge su strane ona načela koja bi se mogla nazvati "(čista) ideološka" načela i nisu izvedena iz aktualnog pravnog sistema. Odnose se na tekuća dominantna vjerovanja u društvu kao što su moral, politika i druge nepravne ideologije. Ona predstavljaju primjenu nepravnih vrijednosti ili normi od strane sudova. Među njih spadaju npr. načelo zabrane napuštanja prava ili pravna sigurnost. ${ }^{142}$

Dakle, kako vidimo, opća pravna načela imaju veoma različito područje primjene: ne postoji ništa zajedničko između primjene načela bogaćenja bez osnove, čija je učinkovitost veoma ograničena i načela prava na obranu, koje se svakodnevno primjenjuje na svim područjima. Ni njihova autoritarnost nije ista: dok postoje načela čija je vrijednost, kako bi se moglo reći samo pravne prirode, dotle se drugim načelima priznaje ustavna vrijednost, npr. pravo na obranu, načelo zabrane retroaktivne primjene zakona u kaznenim predmetima ili načelo neovisnosti sudova. ${ }^{143}$

\section{POPUNJAVANJE PRAVNIH PRAZNINA KAO TEHNIKA ZA UPOTPUNJAVANJE PRAVNOG SISTEMA}

Polazimo od pretpostavke da je pravo, u cijelosti, ili barem djelomično, "sistematskog" karaktera, tj. da nema pravnih praznina, antinomija (proturječja između pravnih normi) i neodređenosti. Te tri osobine izražavaju se kao potpunost, koherentnosti i određenost, i ujedno

\footnotetext{
138 Van Hoecke, Law..., op. cit. u bilj. 128, str. 161.

139 Loc. cit. Takvu mogućnost predviđaju npr. čl. 12. Talijanskog građanskog zakonika, koji upućuje na "opća načela pravnog poretka države", čl. 10. Portugalskog građanskog zakonika upućuje na "duh pravnog sistema”, čl. 38. Statuta međunarodnog suda pravde poziva se na "opća pravna načela priznata od civiliziranih naroda”. (Primjere daje Van Hoecke, Law..., cit. u bilj. 128, str. 162.). 
predstavljaju načela prava. ${ }^{144}$ Ove osobine su, s jedne strane, stvarno stanje pravnog sistema, jer svaki pravni sistem ostvaruje visok stupanj potpunosti, koherentnosti i određenosti, a $s$ druge strane su i pravni ideali koje pravni poredak ostvaruje ili tek treba ostvariti.

Nama je najinteresantnija osobina potpunosti pravnog sistema - načelo potpunosti, koje bi se trebalo ostvarivati popunjavanjem pravnih praznina.

Danas se priznaje postojanje pravnih praznina. Polazi se od toga da pravo teži potpunom obuhvatu odnosa koji su njegov predmet, ali zbog njihove složenosti, dinamičnosti i promjenljivosti to u svim slučajevima ne uspijeva, pa društveni odnosi ostaju nenormirani ili nedostatno normirani.

Mogućnost postojanja pravnih praznina nije se uvijek priznavala. ${ }^{145}$ Prema najstarijoj, ali i dalje prisutnoj legalističkoj koncepciji, pravo se shvaća kao izraz volje zakonodavca, pa onda treba poštovati i zahtjev zakonodavca da svi pravno relevantni odnosi budu uređeni pravom. Dakle, pravni sistem je potpun i nema praznina jer zakonodavac tako naređuje. ${ }^{146}$

Druga koncepcija koja shvaća pravo kao jedinstvo općih i individualnih normi, i pri tome naročito ističe ulogu suca, kaže da pravne praznine postoje s obzirom na zakon, ali ne i s obzirom na pravo u cjelini budući da sudac također stvara pravo i mora riješiti svaki sporan pravni slučaj. ${ }^{147}$

Kako smo naveli, postoje različita shvaćanja pravnih praznina. Osnovno je značenje praznina kao društvenih odnosa koji nisu, ali bi zbog svoje važnosti trebali biti normirani. To su normativne pravne praznine. ${ }^{148} \mathrm{Uz}$ to praznine shvaćamo i kao tehničke praznine i vrijednosne praznine. ${ }^{149}$

Za popunjavanje praznina predviđeno je više sredstava. Na prvom mjestu svakako je argument analogije, kojeg se katkad smatra za postupak tumačenja u strožem smislu, a ne za metodu eliminiranja praznina. ${ }^{150}$ Obično se ističu dva njegova oblika - analogia legis, kod kojeg se praznina popunjava primjenom jedne pravne odredbe, i analogia iuris, kod koje se praznina popunjava primjenom nekog načela na neregulirani odnos. Analogija dolazi u obzir samo ako između nenormiranog i normiranog odnosa postoji bitna sličnost, a što se utvrđuje ciljnim

144 Miličić ističe da se dugovječno u predavanju dogmatike prava raspravlja manje više (samo) o dvama načelima sustava prava: načelu potpunosti i načelu skladnosti (Miličić, op. cit. u bilj. 131, str. 69.). O određenosti kao načelu pravnog sistema od hrvatskih autora još govore Visković, Pojam..., cit. u bilj. 132, str. 250., 253., te Vrban, op. cit. u bilj. 58, str. 426., 427.

145 Vidi supra, bilj. 95.

146 Pravno su relevantni samo oni društveni odnosi koje je zakonodavac normirao, a "pravne praznine ne postoje ili zato što je zakonodavac ravnodušan na sve ostale odnose ili zato što je on prešutno kvalificirao i sve ostale odnose kao dozvoljene” (Gény, F., Méthode d' interpretation et sources du droit privé positif, LGDJ, Paris, 1919., t. I., str. 70. i dalje).

147 Vidi infra, bilj. 96.

148 Guastini ih pak definira kao pojavu da zakonodavac uredi niz činjeničnih stanja, ali propusti urediti jednu ili više njihovih mogućih kombinacija (Guastini, op. cit. u bilj. 97, str. 367.).

149 Postoje npr. i početne i naknadne, prave i neprave pravne praznine.

150 Razlikovanje tumačenja i popunjavanja pravnih praznina jedno je od spornih pitanja u pravnoj znanosti. Ono se većinom razrješava tako da se kaže da tumačenje pretpostavlja da za slučaj o kojem treba odlučiti postoji pravna odredba, dok naprotiv popunjavanje praznina pretpostavlja da za slučaj nije predviđena odredba (tako npr. La Torre, Pattaro, Taruffo, op. cit. u bilj. 106, str. 218.). Moguće je, kako Perelman kaže, da u pravnim sistemima postoji kolebanje, pa da ono što jedan sistem smatra tumačenjem, može u drugom biti kvalificirano kao popunjavanje praznine (Perelman, Ch., op. cit. u bilj. 105, str. 135.). Držimo da u praksi ne postoji stroga granica između tumačenja argumentima a simili i popunjavanja praznina te da sudac kad upotrebljava argument a simili istodobno popunjava i pravnu prazninu. 
tumačenjem. Nadalje, u pravnoj teoriji se, ovisno o pravnim sistemima, navode još i sljedeća sredstva za popunjavanje praznina: načela prirodnog prava, opća pravna načela, norma iz usporednog prava, pravila društvenog morala, norma koja je nekad važila, običaji, norma koju sudac donosi prema osjećaju pravičnosti, norma koju preporučuje pravna znanost, norma prirodnog prava, argument a fortiori, argument a contrario. ${ }^{151}$ Prikažimo stajalište prema kojem se pravne praznine popunjavaju argumentom a contrario. Naime, postoje slučajevi koji sliče pravnoj praznini, ali nisu slučajevi pravnih praznina, već su pravom regulirani odnosi i prema tome rješavaju se tumačenjem. Ti slučajevi su regulirani pravom - ali negativno. Argumentom a contrario iz jedne izričite normativne kvalifikacije (ovlaštenja, obveze) nekog ponašanja zaključuje se da postoji suprotna prešutna kvalifikacija drugog ponašanja). ${ }^{152}$ Kažemo da, ako je nešto u pravnom tekstu izostavljeno, na to se primjenjuje suprotna normativna kvalifikacija - ako se normom nekome nešto zabranjuje, onda je onome koji je izostavljen to dopušteno, a ako se normom nekome nešto dopušta, onda je onaj kome je izostavljen, to zabranjeno. ${ }^{153}$

Na vjerovanju da pravni sistem osigurava potpuno discipliniranje - lišeno praznina, temelji se argument a completudine.

Ostale su dvije osobine pravnog sistema manja ili veća nekoherentnost i određenost.

Načelo koherentnosti zahtijeva da u pravnom sistemu nema antinomija. Antinomije pak postoje kada dvije ili više normi isto činjenično stanje discipliniraju na različite i nekompatibilne načine, tako da se sve ove norme ne mogu istodobno primijeniti, jer primjena jedne krši drugu i obratno. ${ }^{154}$

Načelo određenosti zahtijeva da sve više pravne norme odrede što potpunije i preciznije sadržaj nižih normi, tako da niži subjekti normiraju u što manjoj mjeri i ne budu slobodni tvorci normi. ${ }^{155}$

\section{ZAKLJUČAK}

Primjetno je da rasprava o analogiji uopće i rasprava o analogiji u pravu obuhvaćaju otprilike podjednak prostor. Možemo upitati zašto je tome tako, odnosno zašto nije, kao što bi to naslov podrazumijevao, veći dio bio posvećen analogiji u pravu. To je zato što je zaključivanje na temelju analogije jedna opća metoda koja se koristi u svim područjima života, pa tako i u pravu. Naravno, analogija u pravu ima neke svoje specifičnosti, naročito kod popunjavanja pravnih praznina.

151 O tome vidi: Ost, F., Van der Kerchove, M., Entre la lettre et l'esprit. Les directives d'interpretation en droit, Bruylant, Bruselles, 1989., str. 3. Visković, N., Pojam..., cit. u bilj.132, str. 250.; D’Alessio, R., Completezza, chiusura e integrazione dell'ordinamento, u: Modugno, F., Appunti per una teoria generale del diritto, Giappichelli, Torino, 1997., str. 253., 280.; Vasić; Jovanović; Dajović, op. cit. u bilj. 21, str. 372., 373.)

152 Visković, Teorija..., op. cit. u bilj. 51, str. 254.

153 Vasić; Jovanović; Dajović, op. cit. u bilj. 21, str. 372.

154 Guastini, op. cit. u bilj. 97, str. 6.

155 Visković, Pojam..., cit. u bilj. 132, str. 250. 
Naročito je, u praksi hrvatskih sudova interesantna upotreba zakonske analogije (analogia legis) i pravne analogije (analogia iuris), i popunjavanje pravnih praznina preko njih. Smatra se da sudovi popunjavaju pravne praznine s pomoću zakonske analogije tako da, umjesto pravne odredbe koju je trebalo primijeniti, a koje nema, pronađe drugu odgovarajuću odredba i ona se primjeni na slučaj. Pravnom analogijom popunjavaju se pravne praznine tako da umjesto odredbe koja bi se trebala primijeniti na slučaj, a koje nema - primjeni neko pravno načelo. Sudovi, iako to izričito ne kažu, upotrebljavaju zakonsku analogiju i njome popunjavaju praznine. Sudovi upotrebljavaju i pravna načela, ali smo skloni mišljenju da njihovom upotrebom ne popunjavaju pravne praznine. Naime, u mnogim slučajevima koriste normirana načela, odnosno načela koja su već ušla u pravne odredbe te tada, pozivajući se na pravna načela - primjenjuju pravne odredbe. Odnosno, primjenjuju pravna načela, ali ne kažu da njima popunjavaju pravne praznine. Skloni smo mišljenju da suci nevoljko upotrebljavaju izraz "pravna praznina".

U tome smislu ide i glavna preporuka ovog rada za daljnjim istraživanjima - znači li i u kojoj mjeri upotreba pravnih načela od strane hrvatskih sudova i popunjavanje pravnih praznina.

\section{LITERATURA}

1. Aarnio, A., Statutory Interpretation in Finland, u: MacCormick, N. D., Summers, R. D., (ur.) Interpreting Statutes, Aldershort (etc.), 1991.

2. Aubert, J.-L., Introduction au droit et thèmes fondamentaux du droit civil, 8. izdanje, Éditions Dalloz, Paris, 2000.

3. Bernejo-Luque, L., The Uses of Analogies, u: Ribeiro Jales, H., (ur.) Systematic Approaches to Argument by Analogy, Springer, 2014., str. 57.-71.

4. Bobbio, N., Eseji iz teorije prava, Logos, Split, 1988.

5. Bobbio, N., Lacune del diritto, u: Comanducci, P., Guastini, R., (ur.) L'analisi del ragionamento giuridico, god. 2, Giappichelli, Torino, 1989., str. 187.-205.

6. Canale, D., Tuzet, G., The A Simili Argument: An Inferentialist Setting, Ratio Juris, god. 22, br. 4, 2009., str. 499.-509.

7. Comanducci, P., Sulle lacune: note in margine a Bobbio, u: Comanducci, P., Guastini, R., (ur.) L'analisi del ragionamento giuridico, god. 2, Giappichelli, Torino, 1989, str. 207.-213.

8. D’Alessio, R., Completezza, chiusura e integrazione dell'ordinamento, u: Modugno, F. Appunti per una teoria generale del diritto, Giappichelli, Torino, 1997., str. 237.-280.

9. Damele, G., Analogia Legis and Analogia Iuris: An Overwiev from a Rhetorical Perspective, u: Ribeiro Jales, H., (ur.), Systematic Approaches to Argument by Analogy, Springer, 2014., str. 243.-256.

10. Dworkin, R., Taking Rights Seriously, Duckworth, Cambridge, 1977.

11. Farrar, J., Reasoning by Analogy in the Law, Bond Law Review, god. 9, br. 2, 1997., str. 148.-175.

12. Geny, F., Méthode d'interpretation et sources en droit prive positif, t. I i II, Libraire générale de droit \& de jurisprudence, Paris, 1919.

13. Grozdanić, V.; Škorić, M.; Martinović, I., Kazneno pravo. Opći dio, Pravni fakultet Sveučilišta u Rijeci, Rijeka, 2013.

14. Guarini, M., Understanding Blended Multti-Source Arguments from Partial Analogies, Ratio Juris, god. 23, br. 1, 2010., str. 65.-100. 
15. Guastini, R., Sintaksa prava (s talijanskog preveo L. Burazin), Naklada Breza, Zagreb, 2016.

16. Harašić, Ž., Sudska argumentacija, Pravni fakultet Sveučilišta u Splitu, Split, 2010.

17. Horvatić, Ž.; Derenčinović, D.; Cvitanović, L., Kazneno pravo. Opći dio 1. Kazneno pravo i kazneni zakon, Pravni fakultet Sveučilišta u Zagrebu, Zagreb, 2016.

18. Juthe, A., A Systematic Review of Classification of Argument by Analogy, u: Ribeiro Jales, H., (ur.) Systematic Approaches to Argument by Analogy, Springer, 2014., str. 109.-127.

19. Kutleša, S., (ur.) Filozofski leksikon, Leksikografski zavod Miroslav Krleža, Zagreb, 2012.

20. La Torre, M.; Pattaro, E.; Taruffo, M., Statutory Interpretation in Italy, u: MacCormick, N. D., Summers, R. S., (ur.) Interpreting Statutes, Aldershot (etc.), 1991., str. 213.-256.

21. Macagno, F., Analogy and Redefinition, u: Ribeiro Jales, H., (ur.) Systematic Approaches to Argument by Analogy, Springer, 2014., str. 73.-89.

22. Maris Cees, W., Milking the Meter - On Analogy, Universalizability, u: Nerhot, P., (ur.) Legal Knowledge and Analogy. Fragments of Legal Epistemology, Hermeneutics and Linguistics, Springer Science+Business Media, B. V., 1991., str. 71.-106.

23. Miličić, V., Metodologija prava - Nomotehnika, Sveučilišna tiskara: Pravni fakultet, Zagreb, 1998.

24. Nerhot, P., Introduction, u: Nerhot, P., (ur.) Legal Knowledge and Analogy. Fragments of Legal Epistemology, Hermeneutics and Liguistics, Springer Science+Business Media, B. V., 1991., str. 1.-11.

25. Novoselec, P., Opći dio kaznenog prava, 5. izmijenjeno izdanje, Sveučilište J. J. Strossmayera u Osijeku, Osijek, 2016.

26. Ost, F., Van der Kerchove, M., Entre la lettre et l'esprit. Les directives d'interpretation en droit, Bruylant, Bruselles, 1989.

27. Pavčnik, M., Argumentacija v pravu, GV Založba, 3. izdanje, Ljubljana, 2013.

28. Perelman, Ch., Pravo, moral i filozofija, Nolit, Beograd, 1983.

29. Perić, D., Država i pravni sustav, 6. izdanje, Informator, Zagreb, 1994.

30. Pezo, V., Pravni leksikon, Leksikografski zavod Miroslav Krleža, Zagreb, 2007.

31. Pokrovac, Z., H. U. Kantorowitz i slobodnopravni pokret, doktorska disertacija, Split, 1995.

32. Poscher, R., Insights, Errors and Self-Misconceptions of the Theory of Principles, Ratio Juris, god. 22, br. 4, 2009., str. 425.-454.

33. Ribeiro Jales, H., Introduction, u: Ribeiro Jales, H., (ur.) Systematic Approaches to Argument by Analogy, Springer, 2014., str. 1.-19.

34. Schauer, F., Spellman, B., Analogy, Expertise, and Experience, The University of Chicago Law Review, god. 84, 2017., str. 249.-268.

35. Summers, R. S., Taruffo, M., Interpretation and Comparative Analysis, u: MacCormick, N. D., Summers, R S., (ur.) Interpreting Statutes, Aldershot (etc.), 1991., str. 46.-510.

36. Tarello, G., Argumentacija tumačenja i sheme obrazlaganja u pridavanju značenja normativnim tekstovima, Zbornik za teoriju prava IV, Beograd, 1990., str. 239.-279. (prijevod dijela knjige L'interpretazione della legge, Milano, 1980.).

37. Van Emeren, F. H., Garsen, B., Argumentation by Analogy in Stereotypical Argumentative Patterns, u: Ribeiro Jales, H., (ur.) Systematic Approaches to Argument by Analogy, Springer 2014., str. 41.-56.

38. Van Hoecke, M., The Use of Unwritten Legal Principles by Courts, ARSP, Beiheft 53, Hans-Joachim Koch/Ulfrid Neumann (Hsrg.) PraktischeVernunft und Rechtsanwendung, Franz Steiner Verlag Stuttgart, 1994., str. 129.-138.

39. Van Hoecke, M., Law as Communication, Hart Publishing, Oxford-Portland, Oregon, 2002., str. 160. 
40. Vasić, R.; Jovanović, D.; Dajović, G., Uvod u pravo, Pravni fakultet Univerziteta u Beogradu, Centar za izdavaštvo i informisanje, Dosije Studio, Beograd, 2014.

41. Visković, N., Argumentacija i pravo, Pravni fakultet Sveučilišta u Splitu, Split, 1997.

42. Visković, N., Pojam prava, 2. dopunjeno i izmijenjeno izdanje, Logos, Split, 1981.

43. Visković, N., Teorija države i prava, 2. dopunjeno i izmijenjeno izdanje, Birotehnika CDO, Zagreb, 2006.

44. Vrban, D., Država i pravo, Golden marketing, Zagreb, 2003.

45. Walton, D. N., Argumentation Shemes for Argument from Analogy, u: Ribeiro Jales, H., (ur.) Systematic Appraches to Argument by Analogy, Springer, 2014., str. 23.-40.

46. Zaccaria, G., Analogy as Legal Reasoning - The Hermeneutic Foundation, u: Nerhot, P., (ur.) Legal Knowledge and Analogy. Fragments of Legal Epistemology, Hermeneutics and Liguistics, Springer Science+Business Media, B. V., 1991., str. 42.-70.

\section{MREŽNI IZVORI}

1. "Analogija", Hrvatska enciklopedija, http://www.enciklopedija.hr/natuknica. aspx?id=2471, pristupljeno 19. kolovoza 2017.

2. Baltha, P., Analogy and Analogical Reasoning, The Stanford Encyclopedia of Philosophy, (Winter 2016 edition), Edward N. Zalta (ed.). https://plato.stanford.edu/archives /Winter 2016//entries/reasoning-analogy/, pristupljeno 27. prosinca 2017.

3. Hunter, D., Teaching and Using Analogy in Law, Journal of the Association of Legal Writting Directors, 2008., str. 151.-168. https://ssrn.com/abstract=1089669, pristupljeno 20. listopada 2017.

4. Juthe, A., Argument by Analogy, Argumentation, god. 19, br. 1, Springer, 2005, str. 1.-27. https:// doi.org/10.1007/s10503-005-2314-9/, pristupljeno 20. listopada 2017.

5. Lamond, G., Precedent and Analogy in Legal Reasoning, The Stanford Encyclopedia of Philosophy (spring 2016 Edition), Edward N. Zalta, (ed.). https://plato.stanford.edu/archives/Spr 2016/entries/legal-reas-prec/, pristupljeno 27. prosinca 2017.

\section{PRAVNI AKTI I SUDSKE ODLUKE}

1. Ustav Republike Hrvatske (Narodne novine, broj 56/1990, 135/1997, 8/1998, 113/2000, 124/2000, 28/2001, 41/2001 41/2001, 55/2001, 76/2010, 85/2010, 5/2014.

2. VSRH, Rev 1446/1988 od 26. ožujka 2003. Izbor odluka 1/2003.

3. VSRH, Rev 1143/2001-2 od 27. siječnja 2004. Izbor odluka 1/2004. 


\section{ANALOGY IN LAW: MEANING AND USE}

\section{Summary}

Conclusions by analogy are common in all areas of human activities, including law. Conclusion by analogy in law can be reduced prima facie to the same form as the conclusion by analogy in general i.e. two premises and a conclusion. However, it differs from analogical conclusion in general, because one premise in law conclusion must be normative (not only factual).

Researches into analogical conclusions (in general and in law) have been done from many aspects and by a number of authors. There is a consensus only on an elementary form, and it is founded on the similarity of two objects (two features) in some characteristics, which draws a conclusion that these objects (features) are similar in some of their features.

When it comes to analogy in law, there are four types of analogies: A statutory analogy (analogia legis), law analogy (analogia iuris), the inter legem analogy, and an analogy we use in law of precedents. These analogies are utilized to interpret legal norms and the loopholes in the law are closed (with exception of criminal law where there are no loopholes). This becomes both particularly interesting and disputable when it comes to legal principles.

Keywords: $\quad$ Conclusion by analogy, similarity, precedents, closing loopholes in the law, legal principles

\section{(c) (1) $(9$}

This work is licensed under a Creative Commons

Attribution-NonCommercial 4.0 International License.

* Žaklina Harašić, PhD, Associate Professor, Theory of Law and State Department, Faculty of Law, University of Split, Domovinskog rata 8, 21000 Split, Republic of Croatia. E-mail address: zaklina.harasic@pravst.hr ORCID:https://orcid.org/0000-0002-43953114 . 